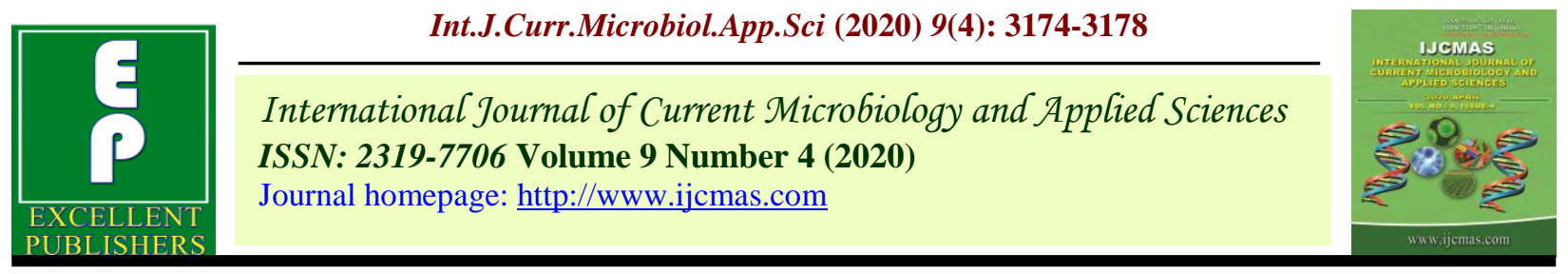

Original Research Article

https://doi.org/10.20546/ijcmas.2020.904.369

\title{
OL 12: A New High Yielding Fodder Oat Variety Released for Punjab State, India
}

\author{
Rahul Kapoor $^{* *}$ and Tarvinder Pal Singh ${ }^{2}$ \\ ${ }^{1}$ Department of Plant Breeding and Genetics, ${ }^{2}$ O/o Director of Seeds, Punjab Agricultural \\ University, Ludhiana - 141 004, India \\ *Corresponding author
}

\section{A B S T R A C T}

\begin{tabular}{l} 
Ke y w o r d s \\
Oat, Single cut, \\
Green fodder yield, \\
Dry matter yield, \\
Quality traits \\
Article Info \\
$\begin{array}{l}\text { Accepted: } \\
28 \text { March } 2020 \\
\text { Available Online: } \\
\text { 10 April } 2020\end{array}$ \\
\hline
\end{tabular}

Keywords

Oat, Single cut, Green fodder yield Dry matter yield, Quality traits

\section{Introduction}

The genus Avena belongs to the grass family Poaceae. It comprises of about seventy species, although mainly $A$. sativa, $A$. nuda and $A$. byzantine are those most commonly cultivated on a commercial scale. A. sativa is an economically important crop and ranks sixth in world cereal production after wheat, maize, rice, barley and sorghum (FAO, 2012). It is an important winter forage crop in many parts of the world and is also grown as multipurpose crop for grain, pasture and forage. It is considered to be one of the best dual purpose cereal crops that fit well into the platter of human and cattle as well. Consumption of oat bran (outer casting of oat) is believed to lower down LDL cholesterol and possibly to reduce the risk of heart diseases. In India, oat is grown as fodder crop during Rabi season in north western and central parts of the country and is now even extending to eastern region as well. In Punjab, oat is grown as fodder crop on 1.0 lac hectares with annual production of 33.6 lac ton (Anonymous, 2018). In recent years, with the advent of exaggerated dairy industry in our country, oat has fascinated the attention of breeders for its improvement due to its nutritious quality fodder for livestock and its 
grains as animal feed with high net energy gains (Ruwaliet al., 2013). More nutritious and high yielding fodder varieties are needed to run an efficient livestock industry on which dependence of increasing population is taking ride.

\section{Materials and Methods}

The Oats variety OL 12 is a derivative of the cross between Kent x OL 125, where Kent is an old introduction of oats from USA into India during late $80 \mathrm{~s}$ and OL 125 is a zonal check of NWZ in AICRP (FCU) trials. The variety has been developed through pedigree selection by combining high green fodder yield as well as better fodder quality. It was tested with the name of 1802-1 in state as well as national AICRP(FCU) trials. The crossing programme was initiated during Rabi 2008-09 at Forage Research Farm, PAU, Ludhiana.

The segregating progenies were selected and advanced during 2010-20014 and the homozygous culture OL 1802-1was evaluated in Station trials with the local checksOL 11, OL 9 and Kent since 2014. It was tested in Multi-location trials in different research Stations of PAU, Ludhiana in 4 locations between 2014 and 2018. Based on its superior performance over check varieties, this variety was assessed in Adaptive Research Trials during Rabi 2017-18 in 52 locations spreading over different oats growing districts in Punjab. Field Screening was carried out for its reaction to pests and diseases. Quality parameters were also assessed for this culture in comparison with the standard varieties. Based on the superiority over the station, MLT, ART, AICRP(FCU) it was proposed for release as OL 12. In 2018, the State Variety Release Committee approved and released it as Oats fodder variety OL 12.

\section{Results and Discussion}

OL 12 has been extensively tested in various research and adaptive trials throughout the state (Table 2). On the basis of 11 Research trials, OL 12 recorded green forage yield of $759.5 \mathrm{q} /$ ha against $702.3 \mathrm{q} / \mathrm{ha}$ of OL $11,612.9$ q/ha of OL 9and 614.4 q/ha of Kent (checks) with advantage of $8.1 \%, 23.9$ and $23.6 \%$ respectively. Likewise, on the basis of 11 Research trials, OL 12 recorded dry matter yield of $146.9 \mathrm{q} / \mathrm{ha}$ against $125.8 \mathrm{q} / \mathrm{ha}$ of $\mathrm{OL}$ $11,110.8 \mathrm{q} / \mathrm{ha}$ of OL 9 and $110.8 \mathrm{q} / \mathrm{ha}$ of Kent (checks) with advantage of $16.8 \%, 32.6 \%$ and $32.6 \%$ respectively.

Table.1 Morphological characteristics of OL 12 and the check varieties of oats

\begin{tabular}{|l|c|c|c|c|}
\hline \multirow{2}{*}{\multicolumn{1}{|c|}{ Characters }} & OL 12 & OL 11 & OL 9 & Kent \\
\hline Plant height $(\mathbf{c m})$ & $\mathbf{1 3 8 . 7}$ & 128.5 & 122.4 & $\mathbf{1 2 4 . 7}$ \\
\hline Leaf length $(\mathbf{c m})$ & $\mathbf{4 1 . 2}$ & 38.1 & 36.5 & $\mathbf{3 5 . 2}$ \\
\hline Leaf width $(\mathbf{c m})$ & $\mathbf{2 . 9 3}$ & 2.51 & 2.45 & $\mathbf{2 . 3 9}$ \\
\hline $\begin{array}{l}\text { Leaf: stem ratio } \\
\text { (LSR) }\end{array}$ & $\mathbf{0 . 8 8}$ & 0.66 & 0.57 & $\mathbf{0 . 6 6}$ \\
\hline Stem thickness (cm) & $\mathbf{0 . 7 8}$ & 0.74 & 0.70 & $\mathbf{0 . 6 6}$ \\
\hline No. of tillers/plant & $\mathbf{1 5 . 8}$ & 13.2 & 11.2 & $\mathbf{1 1 . 8}$ \\
\hline No. of leaves/plant & $\mathbf{6 4 . 8}$ & 56.5 & 50.6 & $\mathbf{5 0 . 2}$ \\
\hline $\begin{array}{l}\text { Number of days from } \\
\text { sowing to harvesting }\end{array}$ & $\mathbf{1 3 5 . 0}$ & $\mathbf{1 2 8 . 0}$ & $\mathbf{1 3 0 . 0}$ & $\mathbf{1 2 9 . 0}$ \\
\hline
\end{tabular}


Table.2 Overall performance of OL 12 and the check varieties in different trials

\begin{tabular}{|c|c|c|c|c|}
\hline \multirow[t]{2}{*}{ Trials } & \multicolumn{4}{|c|}{ Green Fodder Yield (q/ha) } \\
\hline & OL 12 & OL 11 & OL 9 & Kent \\
\hline Research trials (11) & 759.5 & 702.3 & 612.9 & 614.4 \\
\hline \multicolumn{2}{|c|}{$\%$ increase } & 8.1 & 23.9 & 23.6 \\
\hline \multicolumn{5}{|c|}{ Adaptive trials (52) } \\
\hline FASS \& KVK (50) & 619.8 & 573.2 & 550.0 & 529.7 \\
\hline Deptt. Agriculture (2) & 638.8 & 592.5 & 531.3 & 471.3 \\
\hline Mean of 52 trials & 620.5 & 573.9 & 549.3 & $\mathbf{5 2 7 . 5}$ \\
\hline \multicolumn{2}{|c|}{$\%$ increase } & 8.1 & 13.0 & 17.6 \\
\hline Mean of 63 trials & 644.8 & 591.0 & 560.4 & 542.6 \\
\hline \multicolumn{2}{|c|}{$\%$ increase } & 9.1 & 15.1 & 18.8 \\
\hline
\end{tabular}

Table.3 Incidence of leaf blight severity on OL 12 and the check varieties under natural conditions

\begin{tabular}{|c|c|c|c|c|c|c|}
\hline \multirow{2}{*}{ Variety } & \multicolumn{2}{|c|}{ 2015-16 } & \multicolumn{2}{c|}{ 2016-17 } & \multicolumn{2}{c|}{ Average } \\
\cline { 2 - 7 } & Leaf blight & Disease & Leaf blight & Disease & Leaf blight & Disease \\
& severity (\%) & Score & severity (\%) & Score & severity (\%) & Score \\
\hline OL 12 & $\mathbf{3 4 . 5 5}$ & MS & $\mathbf{2 3 . 3 3}$ & MR & 28.94 & MS \\
\hline OL 11 (check) & 40.00 & MS & 24.33 & MR & 32.17 & MS \\
\hline OL 9(check) & 54.67 & S & 49.67 & MS & 52.17 & S \\
\hline Kent (check) & 55.52 & S & 51.33 & S & 53.43 & S \\
\hline
\end{tabular}

Disease Score: (<10\%): Resistant; (10.1-25.0): Moderately Resistant; (25.1-50.0): Moderately susceptible; (50.175.0): Susceptible; $(>75.0 \%)$ : Highly susceptible

Table.4 Incidence of oat aphid, Rhopalosiphumpadi on OL 12 and check varieties under natural conditions

\begin{tabular}{|l|c|c|}
\hline Entry & *No. of aphids/tiller & No. of tillers/plant \\
\hline OL 12 & 3.33 & 13.33 \\
\hline OL 11 & 2.33 & 12.66 \\
\hline OL 9 & 2.00 & 9.33 \\
\hline Kent & 2.33 & 11.00 \\
\hline
\end{tabular}

Figures in parentheses are square root transformations 
Table.5 Quality parameters of OL 12 and check variety evaluated in metabolic trial conducted by Deptt. of Animal Nutrition, GADVASU, Ludhiana

\begin{tabular}{|l|c|c|c|c|}
\hline & Proposed & \multicolumn{3}{|c|}{ Check Varieties } \\
\hline Trait (\%) & OL 12 & OL 11 & OL 9 & Kent \\
\hline Crude Protein -CP & 8.1 & 7.7 & 7.7 & $\mathbf{7 . 9}$ \\
\hline Acid Detergent Fibre -ADF & 44.1 & 44.8 & 44.4 & $\mathbf{4 4 . 2}$ \\
\hline Neutral Detergent Fibre- NDF & 65.4 & 65.9 & 67.5 & $\mathbf{6 5 . 6}$ \\
\hline In vitro Dry Matter Digestibility- IVDMD & 56.9 & 55.7 & 56.1 & $\mathbf{5 6 . 5}$ \\
\hline $\mathrm{NO}_{\mathbf{3}}^{-\mathbf{1}} \mathbf{N}$ content $(\mathbf{p p m}) *$ & $\mathbf{4 1 0}$ & $\mathbf{4 0 0}$ & $\mathbf{7 0 0}$ & $\mathbf{6 8 0}$ \\
\hline
\end{tabular}

Fig.1 OL 12: a new high yielding fodder oats variety

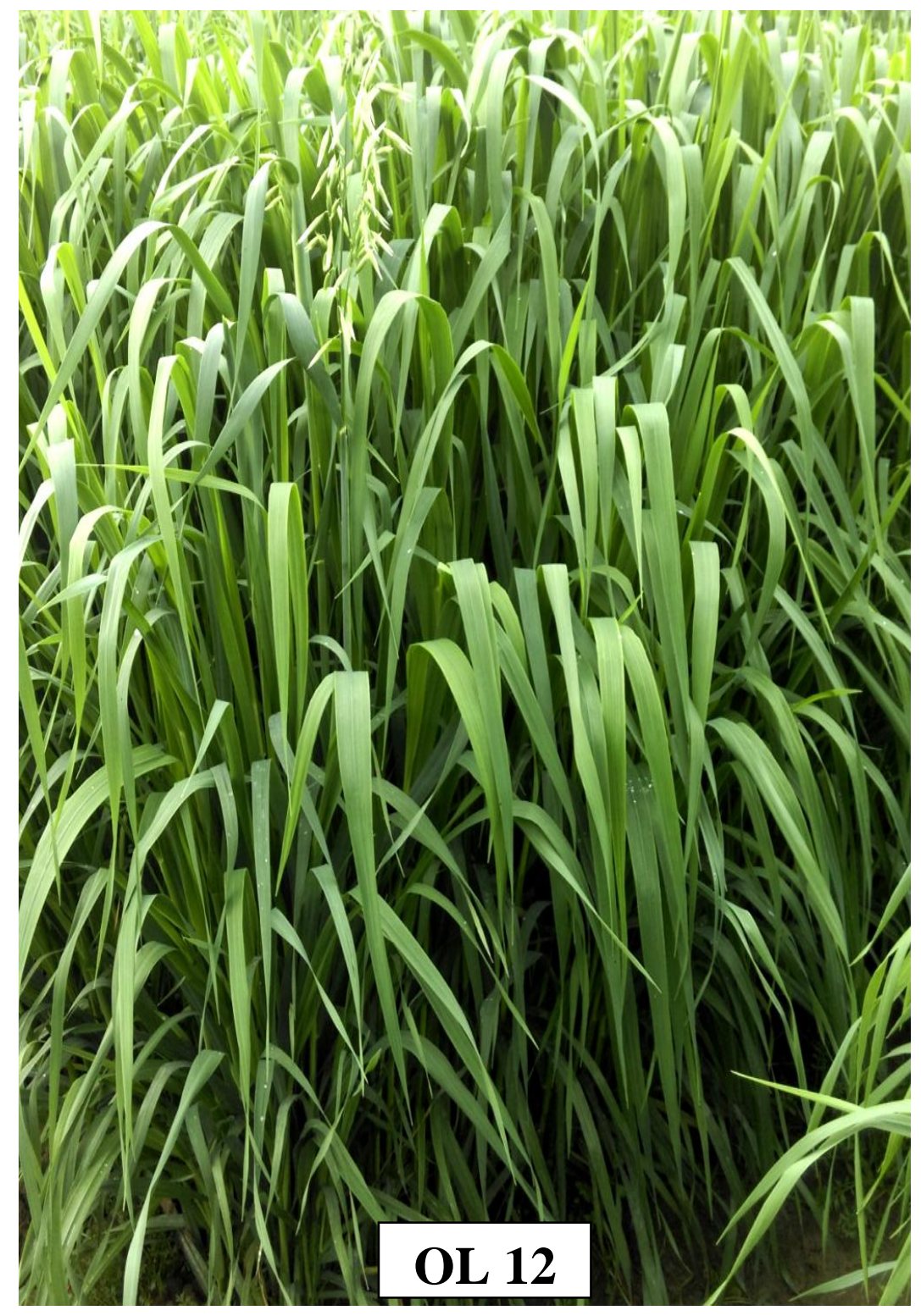


In 52 adaptive trials OL 12 out yielded the checks OL 11, OL 9 and Kent by 9.1\%, $15.1 \%$ and $18.8 \%$ respectively for green fodder yield. It was also tested in the All India Coordinated Research Project on Forage Crops trial conducted during Rabi 2014-15 to 2016-17 in NWZ under the name OL 12 and out yielded both the national checks viz; OS 6 and OL 12 gave moderately susceptible reaction to leaf blight under natural conditions (Table 3).

Regarding the insect pests, non-significant incidence of number of aphids/tiller (Table 4) was observed under natural conditions on OL 12. The green fodder quality characteristics of OL 12 have been given in Table 5. Its fodder quality is superior in terms of total digestible nutrients (TDN) and digestible crude protein (DCP) than checks viz; OL 11, OL-9 and Kent.

\section{References}

Anonymous. 2018. Package of Practices for Rabi crops in Punjab State. PAU, Ludhiana

FAO. 2012. Production Statistics. Food and Agriculture Organisation, Rome.

Ruwali, Y., Singh, K., Kumar, S. and Kumar, L. 2013. Molecular Diversity Analysis in Selected Fodder and Dual Purpose Oat (Avena sativa L.) Genotypes by Using Random Amplified Polymorphic DNA (RAPD). Afr. J. Biotech., 12(22): 3425-29.

\section{How to cite this article:}

Rahul Kapoor and Tarvinder Pal Singh. 2020. OL 12: A New High Yielding Fodder Oat Variety Released for Punjab State, India. Int.J.Curr.Microbiol.App.Sci. 9(04): 3174-3178. doi: https://doi.org/10.20546/ijcmas.2020.904.369 